\title{
"The Shape of Wooden Bridges." Technology, History and the Public: An Interview with Susan Smulyan
}

Didier Aubert and Susan Smulyan

\section{(2) OpenEdition \\ 1 Journals}

Electronic version

URL: https://journals.openedition.org/transatlantica/17460

DOI: 10.4000/transatlantica. 17460

ISSN: $1765-2766$

\section{Publisher}

Association française d'Etudes Américaines (AFEA)

\section{Electronic reference}

Didier Aubert and Susan Smulyan, "'The Shape of Wooden Bridges." Technology, History and the Public: An Interview with Susan Smulyan", Transatlantica [Online], Hors-série | 2021, Online since 01 October 2021, connection on 11 October 2021. URL: http://journals.openedition.org/transatlantica/ 17460 ; DOI: https://doi.org/10.4000/transatlantica.17460

This text was automatically generated on 11 October 2021.

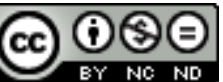

Transatlantica - Revue d'études américaines est mise à disposition selon les termes de la licence Creative Commons Attribution - Pas d'Utilisation Commerciale - Pas de Modification 4.0 International. 


\title{
"The Shape of Wooden Bridges." Technology, History and the Public: An Interview with Susan Smulyan
}

\author{
Didier Aubert and Susan Smulyan
}

\section{Introduction, by Didier Aubert}

1 Transatlantica was launched as an open-access academic journal in 2001, and the tragic political context of the time loomed large in the first issue, which devoted several papers to early reflections on 9/11. In retrospect, the project was also fairly bold in its attempt to get an early start in electronic academic publishing, and open access content. Only four years earlier, in a groundbreaking article in The Journal of American History Michael O'Malley and Roy Rosenzweig felt it necessary to provide readers with definitions of terms such as "World Wide Web," "browser," and "search engine" (O'Malley and Rosenzweig). The authors felt that the web presented "a radically new paradigm or way of thinking," which led to numerous questions about the hierarchy of information, its accuracy, and issues of cultural authority. JSTOR and Project Muse had been launched in 1995 (the year I personally heard the word "Internet" for the first time), and Cairn, a portal which has since become a major aggregator for Frenchlanguage academic journals, only came about in 2005.

Contrary to what one might expect, reading O'Malley and Rosenzweig today reveals less about how far we have come in terms of digital literacy and web browsers' algorithms (not everyone remembers that Yahoo! had a topical directory and Magellan provided ratings of the "best" websites), than about the continuity of debates surrounding the ways this "new paradigm" has affected research, publishing, and teaching. Their survey of the new perspectives (and risks) induced by the new digital tools came at a time when New York University historian Thomas Bender lamented the fact that US universities' achievements in terms of output, diversity, and international leadership had led to a paradoxical, yet "pervasive sense of unease" which undermined faith in the 
mission of higher education, "its civic role," and the "informal compact between the university and society" (Bender 3). His prognosis was largely influenced by the "culture wars" context, but it is worth noting that O'Malley and Rosenzweig hailed the Internet as an "extraordinary tool for making new connections" and facilitate "dialogue about the past's meaning" among "professionals, enthusiasts, artists, educators, politicians, in casual hobbies and obsessive interests, from communities to university classrooms" (O'Malley and Rosenzweig 154). Even before they were really called "digital," 2 humanities mediated through the "world wide web" were already imagined as serving a public interest in ways that might rejuvenate the university's compact with society. By 2010, Gregory Jay reiterated that "the future of the humanities [depended] upon two interrelated innovations: the organized implementation of project-based engaged learning and scholarship, on the one hand, and the continued advancement of digital and new media learning and scholarship, on the other hand."

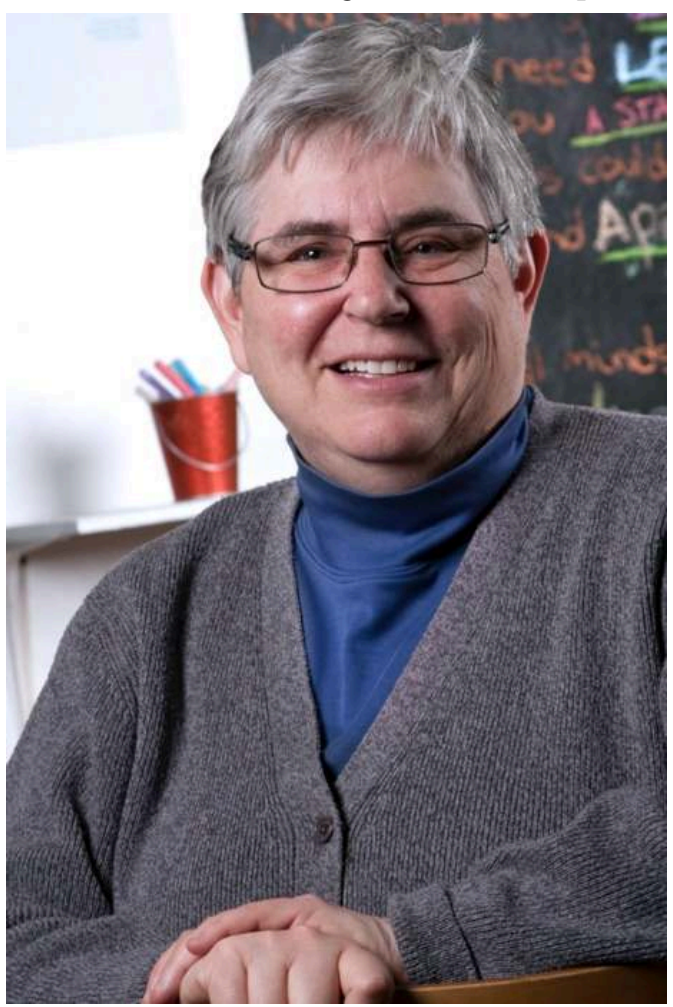

Susan Smulyan. Department of American Studies. Brown University.

A longtime director of the John Nicholas Brown Center for Public Humanities and Cultural Heritage at Brown University, and a historian of US mass and popular culture (Smulyan, 2007) teaching at Brown's American Studies Department, Susan Smulyan has dedicated much of her career to projects combining research, teaching, and a growing commitment to the "civic role" of academics both within and outside the university. In a recent book entitled Doing Public Humanities, she calls for engaged work that is "collaborative, process-driven, and politically-based." "Research and learning," she writes, "must grow from projects developed off-campus, as well as on" (Smulyan, 2021 36). It seemed a good idea to ask her how she saw the development of these "new connections" between digital scholarship, teaching, and engagement imagined by Roy Rosenzweig-who was also instrumental in directing Smulyan's attention to the incoming digital revolution. 


\section{Transcript of the interview}

DIDIER AUBERT: I'd like to begin with a review you wrote in American Quarterly more than twenty years ago (Smulyan, 1999). Was this your first approach to digital scholarship? As I understand it, Roy Rosenzweig introduced you to what was then a new field.

Susan Smulyan: I think it was. Roy was a good friend, which isn't saying much because Roy was a good friend and mentor to many, many, many people. He was at George Mason University, starting the Center for History and New Media, which was named for him after he died. He must have been five or six years ahead of me. He was a graduate student at Harvard when I was at Yale. And when I got to the National Museum of American History as a pre-doctoral fellow, I looked him up because we'd known each other. He was an early adopter-beyond early even. He was a leader in the field that wasn't even a field.

I had always been interested in the history of technology. I was working on the history of radio. I always say I got interested in the Internet because you could watch it develop, as if you could "live" radio history. You didn't have to read about it. You could see what it felt like not to know the end of the story. I liked getting back to feeling that you don't know what is going to happen. And it's always like that with the introduction of new technology.

And here was something that was going to be the biggest thing in my lifetime, maybe ever. Or maybe just of the century. We don't know yet, right? So to watch that unfold was so cool. It struck me that the best way to understand it was to dive in and be part of it. That process would make you a better historian because you were living through the processes that you were describing.

Thinking of radio, I kept saying to myself, "OK, so now we're about nineteen-twentyone. Now we've made it to twenty-four, etc." In fact, in the radio book (Smulyan, 1994), I talk at the end about the Internet and how it's going to be commercialized. I was interested in that.

Roy was someone to talk about that with. When we founded our own Center for Public Humanities at Brown [in 2002], he was one of the people I wanted to apply as director. But he was a deep populist. Trained at Harvard, but he wasn't going to leave the state school (George Mason) which had given him his first job. Literally, that's why he didn't apply. He wasn't going to leave the state school where they let him wheel and deal and set up this great center with a really different kind of mission. And I think he was right that in the United States, state-funded universities have a public mission that the privates don't. The mission of private universities is to the wealthy students who will support them after they graduate. That's what they're selling. They are self-perpetuating institutions and their goal is to self-perpetuate. Public universities have a slightly different goal. It can be easier to do public work with that platform, and he wasn't willing to make a change.

Early on, the link between digital and public scholarship seemed important to Roy. He went all in on digital because he saw it as a form of public history. He saw those deep connections. He thought digital humanities and digital history would be democratic, in the way everything he did was aimed at being democratic. Most of the rest of us just were followers who might not have seen that bigger picture. 
D.A. What you were saying about experiencing a turning point in technology is something I have found very challenging in terms of teaching. It's difficult to bring my students back to a world before photography, for example. I try to help them realize how tremendous a revolution this new technology was. But I don't think I can convey the magnitude of this. They can understand it rationally, yet the experience of it is very hard to get across.

S.S. Well, one thing I used to try was getting them to think about the world without the Internet, but now they can't do that anymore. For the radio there's some short stories that help show the isolation of a pre-broadcast world. Willa Cather, in "A Wagner Matinee" (1904), has a Boston nephew taking his aunt from the country to hear a concert. Her extreme reaction reminds her nephew and the readers of how, before records and radio, if you lived outside a city you just didn't hear music. I used to show students Currier and Ives prints and say, "OK, this is all you saw in the world." And the front pages of newspapers, with bad line drawings. But it's hard.

D.A. Do you still work on the radio and the way it's been transformed by the Internet? Do you still teach it?

S.S. I teach a course on radio. Now students are really interested because they love podcasts-a lot more than I do. But then, everybody loves radio more than I do. I studied it, I like it, but I'm a TV kid. Students just love podcasts, so I make them slog through the history of radio, and listen to old stuff. When I started, it was really hard to get old radio programs, but now, they're everywhere.

D.A. In what sense is this still radio, though? That's the question I have with photography. I'm not sure what you see on Instagram still qualifies. Not in terms of aesthetics, of course -but the technology, the economy, the culture of digital photography are so different now.

S.S. Well, I wasn't sure either. So I just I thought it was a good, authentic question for the students: “Convince me or tell me." They didn't know about radio. So they always think podcasts are radio; they say it's radio. But then, if you look at the whole history of radio, does a podcast do all things that broadcast radio did? Susan Douglas says there's something essentially different about sound right in your ear and going into your brain (Douglas 25-26). And so I've labeled her for class purposes a "radio essentialist." Radio, according to these believers, is different than photography or film because it enters your brain more directly.

And now podcasts get to be radio. But radio, I've always said, is the most flexible medium. So it's one thing until there's a new technology and then it's something else. So point-to-point moved to broadcasting, and then on to transistors and FM, and then long-form programs and then radio becomes a music box, playing hits instead of programs when TV comes. It's always changing. And one person's radio is never the next generation's radio. Everybody calls what they grew up with "the Golden Age of radio." There's probably 15 "Golden Ages of radio"!

D.A. Then it becomes a history of listening rather than the history of the radio, maybe...

S.S. Maybe, radio is just the catch-all word for all kinds of listening. But that's not how people define it. The common usage is, "anything you grew up with." But for the students, it turns out to be a good question. They get to go ask people, their parents, about the definition of radio and they get to trade podcasts, which is their favorite part of the class. In the beginning of the course, I get in either a hobbyist or a physics graduate student, and we all build crystal radio sets because the key to understanding radio is that you don't plug it in. The waves are out there. You can just 
grab them. You don't need to understand much about the technology. But that's one piece that I think is useful. And at the end of the class, the students make podcasts.

D.A. Well, I didn't think we would spend so much time talking about the radio specifically, but our relationship as scholars and teachers with media and technology is really the point here.

S.S. Our relationship to media and technology is the important question. And radio is the first time I ask that question. You ask it with photography. It's linked to the difference between producers and audience or when the audience gets to be the maker. One of the questions with radio is that this changes along the way. Sometimes the technology is accessible enough that everyone can have a role, and then sometimes it gets so expensive and elaborate that you can't. You couldn't possibly produce the Jack Benny show, but my students can now make podcasts. And then it changes again, the technology is more accessible and then it gets commodified and bigger, and audience participation goes away. And that happens with photography, too, right? It's available to everyone. So the professional photographers have to decide what it is they have that the Instagram or the selfie takers don't have. So that, to me, in some ways mimics the introduction of the digital into the scholarly world.

D.A. In a way, that was the question you seemed to raise in "Everyone a Reviewer?" (Smulyan, 1999). Digital tools seemed to democratize access to knowledge and to undermine claims of expertise at the same time.

S.S. The digital opens it up, and then people have to think about what makes them the expert. If the archives are open to everyone, then where does the scholar stand? Our job was to go to the archives and supposedly we brought special skills to our archival work. But most of our "specialness" was that the archives weren't open to everybody. And so we got special skills by the fact that we practiced and went to the archives. We went with special skills, but we gained them by working in the archive as well. And then we brought back and analyzed the materials that we found there.

But if you digitize archives and they're available to all, it changes at least a couple of things. One thing is that scholars who couldn't afford to go to the archives, who were surely scholars but never recognized as such, have an equal shot. And I'm actually thinking about high school social studies teachers, who will tell you that. When I worked with social studies teachers in the 90s, their main goal was to enter these elaborate programs at universities that had been set up to instruct them. The only thing they wanted out of this was access to the archives, to copy things and take them back to their classroom. That's all they wanted because they didn't know how to get stuff otherwise. They wanted to work with primary source documents, but they didn't have access to university libraries. They didn't want to hear the college professors lecture them on anything, let alone the Civil War on which they were much better experts than I, for example.

And then there were many people who just sort of wandered through. I mean, I don't really know who uses digital archives and nobody keeps very good records. But I think it changes how we think of our own work. If anyone can get there, then what are we better at? Maybe we're better at analysis. Maybe we're better contextualizers because we spend a lifetime learning the history. I think that's true.

Asking "what is an expert" also applies to teaching-and to the move to what I used to call constructivist pedagogy, but which now I think they're mostly calling "transformational," which I find a little overweening. But think of the sort of funny 
and corny phrase that people used to say, "rather than a sage on the stage, you are a guide on the side." I took that into scholarship as well. "Here's the archives. Here's what you could do with them. Here's what I see when I go there." But for some scholars, it's a really diminished role. Roy Rosenzweig would say digitizing archives makes things more democratic and changes the role of the scholar. It's a more publicfacing role because the materials are available and there is a ready audience for a scholar to talk about them.

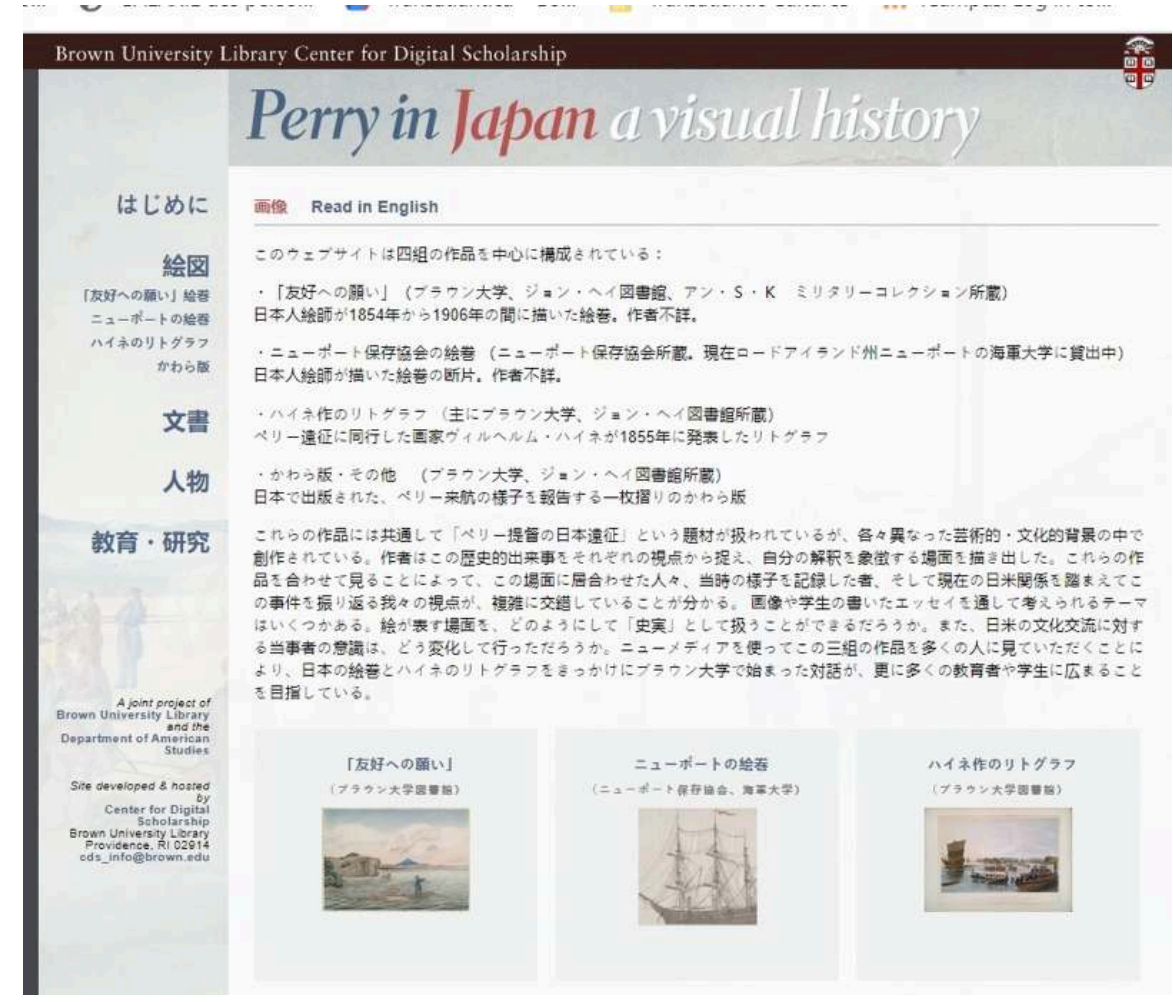

Figure. Screenshot of the "Perry in Japan" website, a collaborative project which explored "the ways in which new media changes teaching, learning and scholarship."

D.A. Ten years after your first foray into the digital, presenting a project called "Perry in Japan" (Smulyan, 2011), you defended the idea of "decentralized" scholarship (you called it "web 1.5"). How did your thinking evolve on this topic?

S.S. I don't think you can change your audience until you change how you think about your scholarship. It isn't good enough to just say, "oh, well, I'll write it in a simpler language." I don't think that's it. You may not want to change, and that's OK. You know, I drink the Kool-Aid on scholarship. I think some work needs to be done just because it's an intellectual challenge and because there'll be ten other people in the world who want to know about this or understand it. And you're working out a problem. That seems to me fine. I think those people should be able to live and be well and do that work, just the way pure science is done.

But if you'd like to reach broader audiences, then you not only have to change what you write about, you have to change how you write it. And you have to think through what the people you're writing for are interested in. So it's a big change when you say you want to move to a different audience or a different public. I see some of that in the work of Transatlantica and that website you are working on, Transatlantic Cultures. ${ }^{3}$ 
I see some of the working out of these issues and questions, but I don't know where it's all going to end.

I think we are also seeing in the United States a change in the media. We're going to be "guides on the side," we're not going to be experts in the same way. But even though everybody's their own media mogul now, everyone isn't Katharine Graham. ${ }^{4}$ And people are reading all sorts of websites, some of which are true and some of which are not. Obviously, there's a whole new set of problems,

D.A. The issue becomes, "how do you make a public, with so much fragmentation?" In a way that's even true about scholarship, as venues for publishing multiply.

S.S. Absolutely, but all changes come with that kind of uncertainty. So you have to work with that ambiguity. And the big lie is that there's no ambiguity in the former model. The problems of the current, or the traditional, formats are huge. And we know them. They keep out people. Only certain kinds of knowledge are privileged. Those problems are enormous. So it's not that there were no problems and now we've created challenges. It's that there was one set of challenges and now we have another one. That's important for me to remember.

There's a Mellon-funded grant at Brown for digital publishing. Brown does not have its own press. They've hired a staff and they're going to do digital publishing. I'm not trying to be judgmental here, but far as I can tell, what they want to do is just publish books that are vetted in exactly the same way, but just not printed. People go to them with more complex ideas. My friend Monica Muñoz Martinez has a digital map that shows the incidence of violence against Mexicans, Mexican-Americans, AfricanAmericans, and Native Americans in Texas. It's a very elaborate digital project. We organized conferences on mapping and there's some really interesting projects out there, but nobody's got figured out how to easily present digital maps yet. And if you could be the ones who figure out the WordPress of mapping, you'd really have done something. So I thought, "they're going to love this." But no, they want books.

There's a very famous historian of technology, I think it's Morrison, who said that for decades after the introduction of iron, people built iron bridges in the shape of wooden bridges because they couldn't conceive of another shape. That was the shape that bridges were. These were just bridges (Morrison 109). And I keep thinking, "these are books." What counts as scholarship-and I don't mean just for promotion or tenure or raises-is so narrow... We haven't even begun to think about what the options might be. The things that are getting funded tend to me to be building iron bridges in the shape of wooden bridges.

People don't like ambiguity. They don't like not knowing what to name it. "That's scholarship. That's not. That's working with the community. That's teaching."

D.A. Reacting to what you said about access to the material and sources that have been digitized-they're just not the material. They are available, but they are something else. So when I think of all the work done on material history, sometimes I wonder if it's a sort of a resistance to the digital and the loss of "expertise." Consciously or not.

S.S. But this is a question that's been there forever. This is "Art in The Age of Mechanical Reproduction." It's not so different from Benjamin. What is the object? And do you have to see it to appreciate it? Was the music on the radio the music, or was it just good enough for ordinary people because that's all they could get? Or was 
it something entirely different that was also good? You could have two different experiences, you know? I think there's a lot of ways to look at that.

I haven't read Benjamin in a really, really long time, but I was thinking about it the other day. We've applied for a National Endowment for the Humanities grant. We want to go into advertising archives to see what work is there that people haven't used. My role was to look at the archives and I got interested in this question: Do you have to be in the archives to see the stuff? Which of it is digitized? What doesn't get into the archive? If we're digitizing this stuff, are we just recreating the master's house?

You know, there is now an emphasis on the archive, in part because cultural studies people just discovered it, and in part because now it's available in a new way. So I think it's worth going back to think about how these get put together. And the same questions come up about the material world. I have a student in Egyptology who's working to do 3-D renderings of cuneiform writings and she's really interesting about the ways in which it's democratizing Egyptology. A lot of people are interested in this material, but is the way in which you digitize it going to change how they think about the object? Which objects are we digitizing-does it simply become a rebuilding of the archives? These questions are really interesting, and I think yours joins that. Are we actually looking at the thing? And what does it mean if we aren't?

D.A. Is this a fetish?

S.S. Well, it's only a fetish if it's all in your mind. I'm not sure it is a fetish. I'm with you that looking at the thing is important. And it strikes me that there are still some things that scholars will have to travel to see. First of all, if you can't see Angkor Wat, how can you write about it? Place/space seems to be the better argument, maybe the clearer argument that you have to be some place sometimes.

We're not getting rid of anthropology because people can zoom. There will still be ethnographies. My students think they do ethnographies because they go and interview people. I tell them, "These are interviews. It can be very useful. Is that an ethnography?" Can you understand a place by interviewing people who live there on Zoom?

D.A. Your involvement with an organization called New Urban Arts $^{5}$ raises similar questions to me, because you've made it very clear in recent years that its "social practice art" is a radical form of humanities, because it is rooted in the community, focusing on process and collaboration rather than product, and motivated by social justice. What strikes me, here again, is a sense of place. "Why don't we do history and sociology and literature in storefronts and row houses?" you ask (Smulyan, 2021 35). It seems in many ways the opposite of the promise of limitless circulation and exchange that digital humanities seem to promise. To put it differently, in academia, as well as social engagement or even environmental activism, is there a growing sense-and possibly a risk-that commitment can only be relevant if it's local and anchored in materiality and practices, rather than utopian transnational perspectives? Are digital tools paradoxically more productive for homegrown activism or "grassroots" humanities (Valk and Ewald)?

S.S. To me, the two things move together at the same time. In the public humanities program, the students came in to a place they'd never been. What we wanted to do was teach them how to learn about a place, and so we went deep locally. Not to be parochial, not to say this is the only place, but to say "this is the place we can go right here, right now." And then to always use that to open out. Here's what we know about this particular place, about these material conditions on the ground. It's just Marx- 
that everything has to be grounded in some set of material conditions, all understanding. What you're always trying to teach students is how to learn, so when you go to another place, what do you do to learn that place or to become part of that community? It's about how to learn about communities.

And two-the more local you get, the more you realize you can't understand it, unless you open out. You can't figure out New Urban Arts if it doesn't force you to think deeply, as it did me about what art means. The big questions come from that grounding in the local.

Our American Studies department just did a search, and candidates told us that we were a department with a reputation for transnational American studies. That's what we wanted, and we went deep into that in a range of different ways. My idea was that every undergraduate and every graduate student should have an international intellectual experience. It changed my life and work, and so I have to think it would change other people's life.

Yet at the very same time, we were starting these public humanities programs that went very deep on the local. And I actually think that the Brown administration didn't understand much about the public humanities, because they don't necessarily feel a strong connection to Providence. So they found the public humanity's deep dive into the local to be parochial. It didn't matter that we raised a hundred thousand dollars a year to take students to Hong Kong for an exchange with the Chinese University of Hong Kong, and they could see the ways in which this kind of community programs led to a revolution in the streets. You know, I thought that was a good lesson.

D.A. But you felt this is institutional and in spite of that, a lot of the faculty members do get involved? Or do you think these are really two worlds?

S.S. I think both. My colleagues in American Studies tend to be more involved, more political than others. Some work in political organizations-prison abolition, jobs, justice. Others are more involved in the arts, some with kids. But the administration wants Brown to be a national and international university, and they see this as a sort of backwater. You do it to make the students happy. You have some engagement. That seems good.

I have written and said that the way in which you do engage scholarship or engage pedagogy should not be to use the local as a lab, which is what the social scientists have done all these years. Sometimes they left good stuff behind, but it didn't really matter. The main point of it was what they learned. It wasn't collaborative with the people they studied. The social sciences have come to their own reckoning with that in whatever community they landed. Everybody's thinking about this. I don't mean that I'm the only one.

It's also true that in the States, often what started as a volunteer center on campus and now is a center for engaged scholarship or pedagogy have a one-way vision of their work. The student is at the center. And the experience of the student is primary because the center is funded by the university. And they worry about the organizations where they send the students only insofar as they don't want them to complain. 
This is not the same as the kind of pedagogy or scholarship that I'm talking about. One group that is looking at scholarship and pedagogy combined is a group that's working on an engaged art history (Benay). But they're struggling with this, because art historians have been so removed. Yet even they talk about the local. "I'm a historian of the Renaissance and I'm here in Cleveland. There's nothing to look at and there's nothing to do... My students don't understand the role of art in people's lives." So how can we try to figure out what these community projects will help them teach their students in a range of ways? Smart, interesting. But art history-whoa! That is a heavy lift. ${ }^{6}$

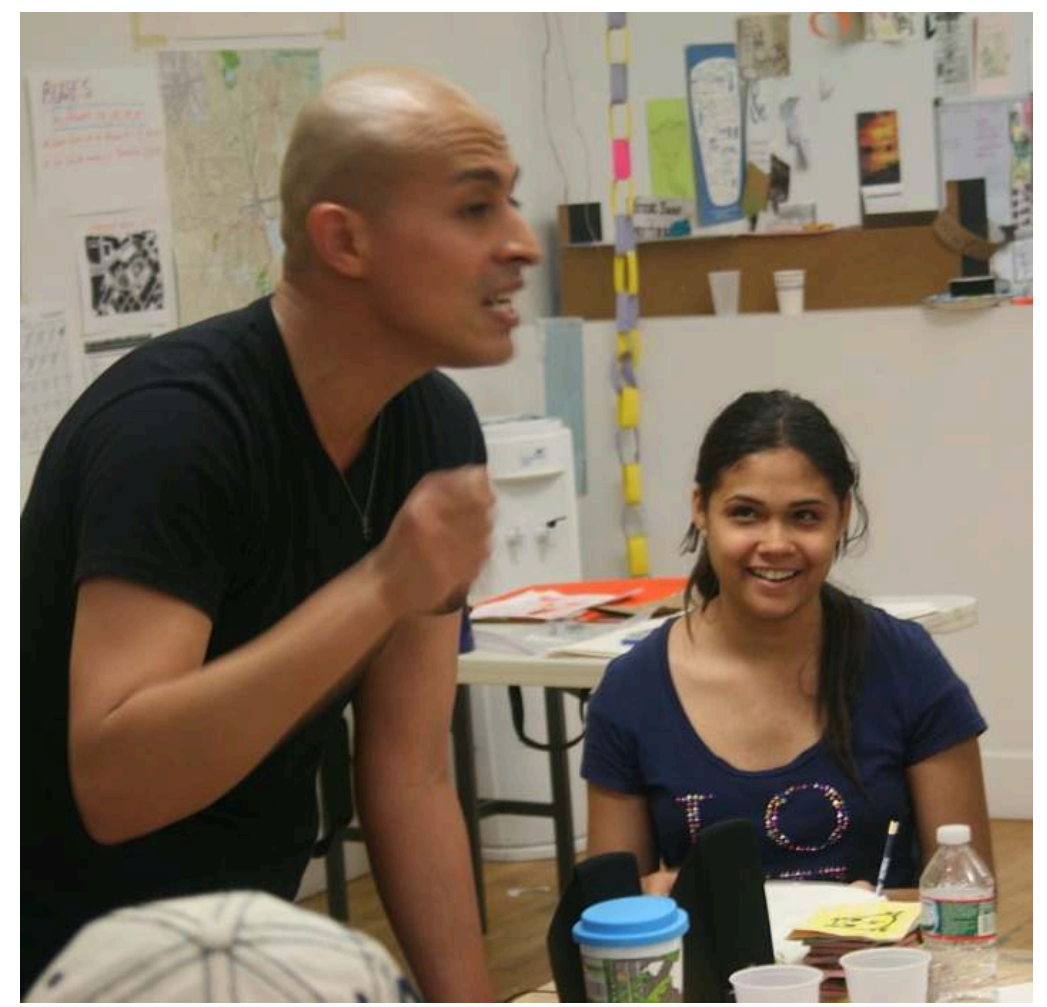

At New Urban Arts, Providence, RI. Photograph by Jesse Banks III.

D.A. Through New Urban Arts you came back to teaching history and engaged scholarship through the practice of art. There's clearly a channel there. Art, whether through photography or painting, now looks at archives and history as a major theme and resource. And many digital and public humanities projects, have something to do with the archive, and the documentation of history. They also need some sort of storytelling, a visual dimension... Art and history seem to combine, to a certain extent.

S.S. I'm a cultural historian, so I'm interested in that. How ordinary people thoughtnot intellectual history or the thinking of intellectuals. Using cultural products to get to that. And I always think that social historians are closer to sociologists. How social structures work. Everyday life, what people do, tells us what they think. I'm closer to a cultural anthropologist, interested in the cultural products, not only art, music, in the traditional sense, but more widely, in the twentieth century, when more people got to be artists, whether it was local theatricals or through the radio.

So New Urban Arts made a lot of sense, and it's a good story. I got frustrated at Brown, as I do once a decade. I wandered off, I went down the hill and I found this. I worked there for ten years, but it was my colleague Bob Lee-revelations in my 
scholarly life almost always come from him-who finally said to me, "This is your work. It's not that you have your work, and then you're doing New Urban Arts. You need to think of this as the work." That helped me. It was a ten-year research project. And then when I became the director of the Center for Public Humanities, there were a lot of people who were really mad. "Oh, she doesn't have any knowledge. She never worked in a museum. She never put up an exhibit." They really saw it as a museum program. And the only way I had to talk to them was to say I chaired the board of this arts program. But now they say they're not going to do arts programs anymore. They're just going back to training our students to work in museums, which I think is shortsighted.

D.A. Back to museum studies?

S.S. It's a little unclear but that's one of the narratives that's out there. It's going to be more-if not high culture, at least museum-based. I think museums are dying, and besides, you can't train people for one thing. You've got to train students flexibly because things are changing all the time. Not everybody can work at the Smithsonian where you don't have to read a budget. Where you don't have to raise money. Where you don't have to write grants, because someone hands you money and then you do a big exhibit.

D.A. Institutionally, how would you evaluate the "strategic" importance of public and digital projects to maintain the relevance of humanities in recent years? In Doing Public Humanities, Robyn Schroeder considers that the development of these programs was also a way to answer "the general pressure that universities have faced to demonstrate efficiency and social utility" (Smulyan, 2021 12). They are also a way to open new job opportunities for humanities students, I suppose? Have you witnessed an evolution in the political economy of digital and public humanities?

S.S. Our students are doing a range of different things. We train two different groups. We train PhDs, with a subspecialty in public humanities. And then we train MAs, who take a range of jobs. A lot of them work at universities-the biggest public humanities project in the country, and in jobs that are not faculty jobs, since a lot of universities are doing this kind of work. They work in libraries. Everybody said, "you'll never be able to train people for libraries because they need librarians' skills." Well, it turns out there's lots of people who put on exhibits in libraries. People do community outreach in libraries.

I insisted we start a list on the website, you know, "truth in advertising." You can see where everybody has jobs and it's a weird, wacky range. I like to think that business schools train students to work in the for-profit section, why can't humanities programs train students to work in the nonprofit sector? And it's also a weird economy that privileges work in the business sector over work in the nonprofit sector. People there are always saying, "oh, well, we should take these lessons from the business sector and apply them to nonprofits." But the nonprofits can do all sorts of things with almost nothing in the United States.

D.A. Like New Urban Arts...

S.S. Yes, but it's all Tocquevillian still in the United States. We're joiners and we help each other. Some people come and say, "My God, New Urban Arts is great. We should all do this." I go, "No, you don't understand. It's because the government is awful that we have to do these things. Or the kids will be lost." But having all these crazy nonprofits is not a good idea. 
I would close New Urban Arts tomorrow if I thought it could get funded the way it should be funded. We look at each other when we go through the fundraising stuff thinking, "This is insane! Why are we doing this?" And every time I travel, New Urban Arts would always ask me to bring back pictures of the after school programs outside the United States. And my answer is, “there isn't anything like this." I tried in Shanghai and in Melbourne for months to find some youth art programs. Of course, their kids are making art somewhere, I just don't know where because I couldn't find them. It's just not labeled like that; programs are part of the schools. I think that's also useful to know.

D.A. Another way in which place, teaching, and history intersect has to do with the public display of art-which is not necessarily "public art" in a strict sense. Recently, you dealt with controversies surrounding the Zuber wallpaper called Vues d'Amérique du Nord (1834) used in the Nightingale-Brown House, where the Center for Public Humanities is located. Some students asked for the paper to be taken down (Smulyan, 2020).

S.S. It's not that we hadn't noticed the wallpaper before the students complained. The Native American faculty, in particular, had been quite unhappy about coming to the Center for that reason. We'd had people visit the Center to speak about it, like Jasmine Nichole Cobb, a faculty member at the University of North Carolina. She'd done this wonderful book on black visuality called Picture Freedom (Cobb), which included a chapter on this exact wallpaper. She came and spoke, and we've been using her essay for a long time as part of our contextualizing efforts.

The original curator of the house put the paper back in in the 1960s when the house was redone. Zuber still prints this, so you can buy it. And in fact it's an interesting moment to think about French visions of the US at that particular time. I think it's actually great for that. And what the first curator, Robert Emlen, and Jasmine Cobb did was to trace one of the images back to a racist lithograph and they knew exactly which one. The original curator's question was whether the French producers were racist, if they didn't have black people in France. You really don't know much about the history of colonialism if you think that people in France didn't know about Africans. But he and the students at the time had long arguments about whether, if the intention wasn't racist, then was this wallpaper racist? This is not an argument I care about. 


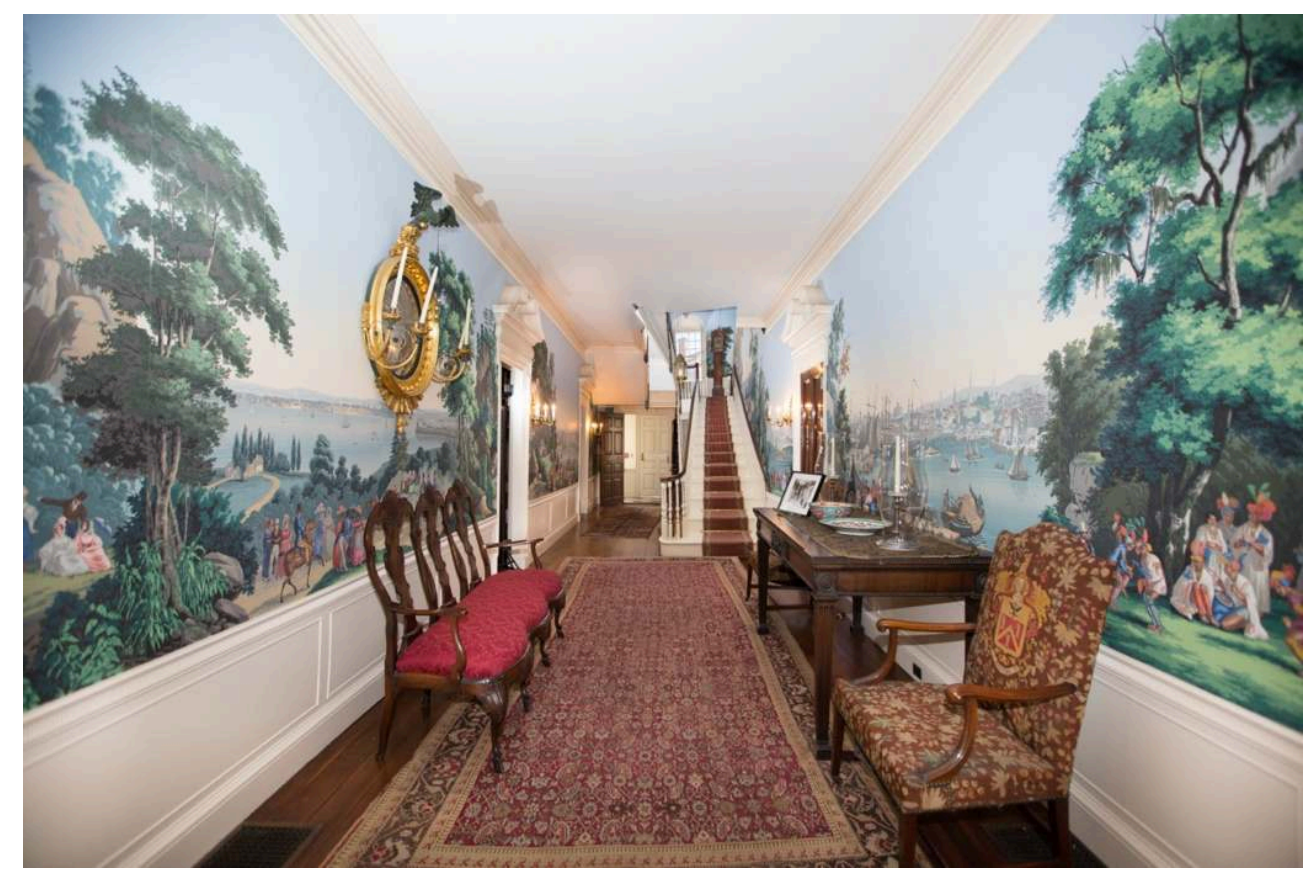

Hall of the Nightingale-Brown House (1792), with the Zuber Company's wallpaper Vues d'Amérique du Nord. Photograph by Jesse Banks III.

D.A. I work very hard to convince students that "intention" is not the most interesting question. I'm not sure they believe me.

S.S. And beyond the question of intention, the other challenge is my own impulse toward collaboration. I would say for me, collaboration ends, and the collaborative impulse or imperative ends, where white supremacy begins. I'm not going to collaborate around racist impulses. If there's some people in the community who want the statues to stay, I'm not collaborating with them because the harm is greater on the other side. And because it's coming out of a system that I don't want to support. But it took me a while to see the students' arguments.

I was perfectly happy to make the wallpaper more visible. You asked about that. That was exactly what I wanted to do. To show the students that we noticed, too. One of their biggest complaints was that no one was talking about it. When they gave each other tours of the house-that's not what happened when we gave tours-they'd go, "and this is our racist wallpaper, but we don't talk about it." And that's not at all what we thought we were doing. But African American people who came in didn't know that we found this wallpaper objectionable too. And that it was a legacy that we were preserving to talk about the fact it was a building block toward white supremacy.

But if they didn't know we thought that, then it wasn't working. We weren't really helping anyone learn something who didn't think about it, and we weren't taking it seriously. In the end, I'd heard enough. People said they felt uncomfortable with it, it made me think it was a real concern. So we tried several things. We put everything about the controversy and the wallpaper in a public Google drive. In addition, we put up Plexiglas panels in front of the wallpaper and we used the panels to post questions and ask for comments on the wallpaper and our questions (Smulyan, 2020). And I tried to assign it in classes, asking the whole class to come over and post. But nobody would do it. I think the students wanted to boycott it. They just wanted the wallpaper 
down. Their attitude was, "you want to play that game?" And I think some of the white students didn't know much about it, they just thought this was a third rail, it was too controversial. They didn't want to be involved.

We did write a flier about the history of the wallpaper, and had that available and had new signage about it. But, if I had stayed on, I think I would have worked hard to take it down. If it were a painting, you could take it down. You might put things up in a museum and tell people "that's what was in this particular house," and you can contextualize it. But in an office building or a school building, I don't think it's possible. ${ }^{7}$ You have to go by it every day.

And the fact is that you can see it in other places. It isn't one of a kind. We don't have to have it. I would be in favor of taking it down and I would work hard to make that happen. Basically everybody else has taken stuff down. Yale took down the stained glass of slaves picking cotton. ${ }^{8}$ And one of the best stories about intentionality is the WPA painting [by Victor Arnautoff] for the George Washington High School in San Francisco. ${ }^{9}$ These murals now made students uncomfortable. More than uncomfortable-they hated it. Yet no one meant any disrespect, and it just was from another time. They couldn't figure out how to take it down in a way that would preserve it, and the students didn't want to cover it. I think that's still being litigated.

Our situation seemed simpler to me. I agreed to go through all the steps, and to try each option along the way. And I think we did that and I would be ready to take the next step. No one's been in the building for eighteen months. So the discussion got cut off a bit.

D.A. Is there a way to find a compromise on this? Could part of the wallpaper be hidden, or would this be a way to ignore the real issue by "sanitizing" this particular instance of a fundamentally racist visual culture?

S.S. The wallpaper is also in the White House. And there's a great picture of the Obamas standing in front of it, blocking one of the most offensive scenes. They knew what they were doing. They lived with this wallpaper, and they just went and stood in front of it. It's a great idea. But I don't think we can get Barack and Michelle to stand in front of those images all the time. And the wallpaper exists as a totality. The negative portrayals are a little more ethnographic in intent but still stereotypes. I think the idea of the wallpaper is that America is a place where everyone mingles and so there's some of that going on. But there's a fair amount of white people looking at native peoples and African American people. It doesn't portray a slave auction so there isn't just one piece to cut out. I'm embarrassed about how long it took me to come round to thinking the way I do now.

D.A. That's what you said earlier about New Urban Arts: "this is your work." It's less about the scholarship per se, in this case, than the mediation between past and present, local and global perceptions, the politics of history and heritage.

S.S. Yes and when you do this kind of work, it's different than so-called objective scholarship. We were always telling the students on the tours about the racism of the wallpaper; we were calling out the racism and mentioning Cobb's book to show the readings we'd done. We were contextualizing, but it's also true that we were contextualizing it intellectually. We were not paying any attention to the lived experience of the students walking by. 
D.A. I don't want to conclude without a word the current situation. In 1997 already, O'Malley and Rosenzweig voiced concerns about the risks of growing inequality of accesssomething we've been directly confronted with during the ongoing pandemic. On the one hand, online classes and distance learning have allowed universities to keep fulfilling their mission. On the other hand, not all students have the same access to these resources-but then again, this might be true of any form of educational resource. The argument could be made that underprivileged students who no longer have to pay for a room in Paris or Providence because their courses are online are no more disadvantaged by technology than they were when they had to live away from their family and pay for room and board on a campus or an expensive city. Does the current crisis affect your perception of the potentially democratizing effect of digital teaching?

S.S. Access is one issue, of course, but it hides a range of issues. The ubiquity of cell phones, around the world, means that most people have Internet access. One question is what platforms do we build our projects on? Students with only cell phones had a hard time accessing their school work, but it wasn't because they didn't have Internet access: it was because schools weren't prepared to meet them on the platform they had available. It's easy to read the New York Times on my cell phone but really hard to read a scholarly article in PDF form. The devil, as usual, may be in the details, and in who pays. Just because a technology has democratic potential doesn't mean it will live up to that potential. And I reserve the right to be disappointed when it doesn't.

\section{BIBLIOGRAPHY}

BENAY, Erin E. "From Campus to Community: Art History as Urban Practice." Journal of Urban Cultural Studies, vol. 8, no 1, 2021, p. 109-119.

BENDER, Thomas. "Politics, Intellect, and the American University, 1945-1995." Daedalus, vol. 126, no. 1, 1997, p. 1-38.

СOBB, Jasmine Nichole. Picture Freedom: Remaking Black Visuality in the Early Nineteenth Century. New York: New York University Press, 2015.

COHEN, Daniel J., and Tom SCHEINFELDT. Hacking the Academy: New Approaches to Scholarship and Teaching from Digital Humanities. Ann Arbor: University of Michigan Press, 2013. Project MUSE, doi: 10.1353/book.22907. Accessed 27 April 2021.

DOUGLAS, Susan J. Listening In: Radio and the American Imagination. Minneapolis: University of Minnesota Press, 2004.

JAY, Gregory. "The Engaged Humanities: Principles and Practices for Public Scholarship and Teaching." Journal of Community Engagement and Scholarship, vol. 3, no 1, 2010.jces.ua.edu/theengaged-humanities-principles-and-practices-for-public-scholarship-and-teaching/. Accessed 27 April 2021.

O'MALLEY, Michael, and Roy ROSENZWEIG. "Brave New World or Blind Alley? American History on the World Wide Web." Journal of American History, vol. 84, no. 1, 1997, p. 132-155. JSTOR, www.jstor.org/stable/2952737. Accessed 27 April 2021. 
MORRISON, Elting E. Men, Machines, and Modern Times. Cambridge: Massachusetts Institute of Technology Press, 1966.

SMULYAN, Susan. "Everyone a Reviewer? Problems and Possibilities in Hypertext Scholarship." American Quarterly, vol. 51, no. 2, 1999, p. 263-267.

SMULYAN, Susan. Popular Ideologies: Mass Culture at Mid-Century. Philadelphia: University of Pennsylvania Press, 2007.

SMULYAN, Susan. "Perry in Japan: A Transnational, Digital, and Pedagogical Project."

Transformations, vol. 22, no. 1, 2011, p. 69-79, 145-146.

SMULYAN, Susan. “Les Vues d'Amérique du Nord.” Brown University Public Humanities Blog, 3 February 2020. www.brown.edu/academics/public-humanities/blog/les-vuesd\%E2\%80\%99am\%C3\%A9rique-du-nord. Accessed 21 June 2021.

SMULYAN, Susan, ed. Doing Public Humanities. New York: Routledge, 2021.

VALK, Anne, and Holly EWALD. "Bringing a Hidden Pond to Public Attention: Increasing Impact through Digital Tools.” Oral History Review, vol. 40, no. 1, 2013, p. 8-24. JSTOR, www.jstor.org/ stable/43863452. Accessed 28 April 2021.

\section{NOTES}

1. This interview was conducted online by Didier Aubert on 11 May 2021.

2. The National Endowment for the Humanities launched its "Digital Humanities Initiative" in 2006.

3. An ANR-funded project, Transatlantic Cultures is digital platform for transatlantic cultural history in four languages. The website will be fully operational by December 2021.

4. Katharine Graham was The Washington Post's publisher between 1963 and 1991.

5. Created in 1997 by college and high school students, New Urban Arts is a non-profit organization which helps high-school students develop artistic projects through mentorship programs, studio space, etc. (Smulyan, 2021 28-38).

6. See the "Building an Engaged Art History" conference, which took place on 22-23 April 2021 at: https://arthist.net/archive/33444

7. It should be added that the Nightingale-Brown House was listed as a National Historic Landmark in 1989 (Smulyan, 2020).

8. In 2016, a Yale university employee named Corey Menafee smashed a stained glass panel depicting slaves carrying bales of cotton in Calhoun College-subsequently renamed Grace Murray Hopper College in 2017. In 2019, the university commissioned Faith Ringgold to design new windows to replace all images celebrating Calhoun's life in the building.

9. Life of Washington, 1936. 


\section{AUTHORS}

\section{DIDIER AUBERT}

Université Sorbonne Nouvelle Paris 3

\section{SUSAN SMULYAN}

Brown University 